\title{
Entrepreneurship Competence in Pre-Service Teachers Training Degrees at Spanish Jesuit Universities: A Content Analysis Based on EntreComp and EntreCompEdu
}

\author{
Arantza Arruti * ID, Cristina Morales and Estibaliz Benitez \\ Education/Faculty of Education and Sports, University of Deusto, 48007 Bilbao, Spain; \\ cristina.morales@opendeusto.es (C.M.); estibalizbenitez@opendeusto.es (E.B.) \\ * Correspondence: aarruti@deusto.es
}

check for

updates

Citation: Arruti, A.; Morales, C.; Benitez, E. Entrepreneurship Competence in Pre-Service Teachers Training Degrees at Spanish Jesuit Universities: A Content Analysis Based on EntreComp and EntreCompEdu. Sustainability 2021, 13, 8740. https://doi.org/10.3390/ su13168740

Academic Editors: Per Servais and Martin Hannibal

Received: 9 July 2021

Accepted: 30 July 2021

Published: 5 August 2021

Publisher's Note: MDPI stays neutral with regard to jurisdictional claims in published maps and institutional affiliations.

Copyright: (c) 2021 by the authors. Licensee MDPI, Basel, Switzerland. This article is an open access article distributed under the terms and conditions of the Creative Commons Attribution (CC BY) license (https:/ / creativecommons.org/licenses/by/ $4.0 /)$.

\begin{abstract}
Entrepreneurship competence is one of the eight key competences for promoting lifelong learning, employability, and ensuring success in the knowledge society. The main objective of this study is to analyse to what extent entrepreneurship competence, as contemplated in the main European reference frameworks (EntreComp and EntreCompEdu), is incorporated into the competences that make up pre-service teachers training degrees offered by Spanish Jesuit universities. A content analysis of 631 competences was carried out by means of an expert judgement. The results of the study allow us to conclude, among others, that: with the exception of Assessment (EntreCompEdu), the remaining areas of both frameworks are covered by $30 \%$ of the competences proposed by the universities; none of the universities incorporate the competences Motivation and perseverance, Financial and economic literacy and Coping with uncertainty, ambiguity and risk of EntreComp, nor Checking and reporting on progress, Share feedback and Recognising progress and achievement of EntreCompEdu; the EntreComp competences Mobilising others, Planning and managing, and Working with others, and the EntreCompEdu Creating an empowering entrepreneurial learning environment are recognised the most; it is in the specific and general competences of the University of Deusto and Ramon LLull University that the above-mentioned competences are most frequently recognised. In conclusion, although there is still much to be done, entrepreneurship competence is included in initial teacher training at Jesuit universities in Spain.
\end{abstract}

Keywords: entrepreneurial competence; higher education; initial teacher education; primary education; EntreComp; EntreCompEdu; jesuit university; pre-service education

\section{Introduction}

Entrepreneurship (En) has gradually gained prominence and importance in disciplines or professional fields beyond business and economics. This is thanks, among others, to the efforts made by the European Commission since the publication of the Green Paper on Entrepreneurship in Europe in 2003 when one of the first references to the importance of entrepreneurship education (EE) was mentioned [1]. From then until today, multiple commissions have taken place, various types of EE plans, actions, and programs have been adopted, launched, and implemented; a wide range of research has been carried out, and; EE has been put in the spotlight [2-13]. Not in vain, En is considered a key element for economic, social, and sustainable development, and, also for the development of creativity and innovation [2,14-21].

In education, one of the most important moments was the publication in 2006 of the eight key competencies for lifelong learning, including entrepreneurship competence (EC) [22]. These are considered as the combination of knowledge, skills, and attitudes appropriate to each context that are fundamental for personal development and fulfillment, the achievement of active citizenship, social inclusion, and employment. 
With the publication of the Entrepreneurship Action Plan 2020 [6], the European Commission invited its Member States to ensure that EC is integrated into curricula at all levels of education, starting with primary education, by the end of 2015. It also encouraged schools to be more entrepreneurial in their approaches in order to ensure the development of a culture of entrepreneurship and innovation throughout their curricula. This is how EE became one of the three areas of immediate intervention and one of the key policy objectives of the European Union and its Member States [23].

At that time, it was argued that efforts were needed to improve initial teacher education in order to familiarise teachers with the subject and the teaching-learning strategies necessary to develop entrepreneurial skills and attitudes in their students [23], as only seven European education systems had EE as a compulsory subject in initial teacher education. Moreover, studies such as Deveci and Seikkula-Leino [24] still maintain today that it is recommended that EE start in primary education and be integrated into all stages of teacher education. Indeed, it seems that, as concluded in the previous Skills Agenda for Europe [25], the measures taken in some Member States to mainstream education were not always done in a coherent way, hence actions to promote it are proposed [9].

The fact is that, although EE and training have grown in recent decades, there are authors who still maintain that entrepreneurial education should be promoted [26], that courses and programs on EE are not sufficiently incorporated into the curricula of higher education institutions [27], and that EE at university level is deficient and generally found in business disciplines [28]. In any case, as Saraiva and Paiva [19] point out, the European Union, the OECD, and the United Nations continue to adopt En as a public policy tool to achieve certain social, environmental, economic, and even cultural objectives.

In the same vein are Ragil et al. [29], who argue that EC should be enhanced in initial teacher education in order to develop it more optimally in primary education; Galvão et al. [30], who argue for the positive impact of EE in increasing knowledge, selfconfidence and skills development; or Zangeneh et al. [31], who highlight the important role played by teachers, one of the key elements in EE, when through example, they show an appropriate attitude and entrepreneurial vision that facilitates the development of creative and entrepreneurial individuals.

A recent study on teachers and EE underlines the challenges we still face in this area. Thus, according to Grigg [11], of the 308 teachers participating in the EntreCompEdu pilot project (the EC reference framework for primary, secondary, and vocational teachers), around $27 \%$ stated that they had no previous experience of EE and 32\% reported they had not heard of EntreComp (the EC reference framework for citizenship).

Therefore, the purposes of this study were to: 1 . compare the competence areas proposed by the European Commission's EC Framework for the citizen (EntreComp) and the EC Framework for the educator (EntreCompEdu) proposed by Bantani Education within the framework of the European Union's Erasmus + program, and 2. based on EntreComp and EntreCompEdu, to analyze the incorporation of EC in the formulation of the competences of the primary education degrees offered by the Spanish Jesuit universities. This could give the authors a clear idea of the importance of EC and to what extent this competence is embedded in the official documents that guide the degrees. A qualitative methodology was followed in this research. A content analysis of the 631 competencies that correspond to the primary education degree offered by the five Spanish Jesuit universities was carried out. It was based on the Order ECI/3857/2007 of 27 December 2007, which establishes the requirements for the verification of university degrees that enable the exercise of the profession of primary education teacher (ECI Order), the information collected from the EntreComp and EntreCompEdu frameworks and the Register of Universities, Centres and Degrees of Spain.

\section{Spanish Context: Pre-Service or Initial Teacher Education in Higher Education}

With regard to Spain, the Ministry of Education, Culture, and Sport [32] noted that it seems that there is not any specific subject on EE in the different initial teacher education 
pathways. On the one hand, the study carried out by Arruti and Paños-Castro [33] on the specialization pathways offered in primary education teacher university degree (primary education degree) show this. On the other, Order ECI/3857/2007 of 27 December 2007, which establishes the requirements for the verification of university degrees that enable the exercise of the profession of primary education teacher, confirms that there is no specific subject on EE [34].

In any case, the latest Spanish law enacted [35], which amends Organic Law 8/2013, establishes in its Article 17 the objectives of primary education. Particularly remarkable is the objective in letter $b$, which insists on the need to develop habits of individual and teamwork effort and responsibility in study, as well as attitudes of self-confidence, critical sense, personal initiative, curiosity, interest, and creativity in learning, and entrepreneurial spirit [36].

Moreover, as Grigg [11] states, the autonomy that enjoys some higher education institutions means that it is not always easy to influence initial teacher education, although studies show that this is possible in some countries [37]. In this sense, the different decrees establishing primary education degrees in the Spanish communities with competencies in education, as in the case of the communities in which the universities whose cases are studied in this research are located, also include the EC, as can be seen in Table 1.

Those are some of the reasons why this research focuses on the situation of Spanish universities with regard to EC, carrying out the first study on the reality of Spanish Jesuit universities. The type of pedagogy and education that the Society of Jesus promotes and the characteristics and competencies related to the EC that constitute the foundations of Jesuit institutions have been essential to choose the universities to be analyzed.

The Society of Jesus was founded in 1540, a time when they opened more than thirty universities around the world. It was suppressed in 1773 and in 1814, after forty years, it was restored, coming back stronger than before. Today, after almost five centuries since its foundation, there are more than two thousand schools, more than two hundred universities and higher education centers, more than one hundred thousand professors and lecturers, and more than two million students linked to it [38].

Almost five hundred years of teaching and learning, convinced that education is power [38] and that education is a means of empowerment to efficiently serve the promotion of justice, the cultural and interreligious dialogue, the environmental cause, reconciliation, the formation of the whole person (conscious, competent, compassionate and committed) and social transformation, among others.

Table 1. Decrees establishing the primary education level curriculum and references to entrepreneurship competence (EC) by the autonomous community.

\begin{tabular}{|c|c|c|c|}
\hline $\begin{array}{l}\text { Autonomous } \\
\text { Community }\end{array}$ & University & Decree & $\begin{array}{l}\text { Entrepreneurial Competence to Be } \\
\text { Developed }\end{array}$ \\
\hline Basque Country & Deusto University & $\begin{array}{l}\text { Decree 236/2015, of December 22, } \\
\text { establishing the Basic Education } \\
\text { curriculum and implementing it } \\
\text { in the Autonomous Community } \\
\text { of the Basque Country. }\end{array}$ & $\begin{array}{l}\text { Article } 7 \text {. Basic transversal } \\
\text { competencies. } \\
\text { (d) Competence for initiative and } \\
\text { entrepreneurship. To show initiative } \\
\text { by managing the entrepreneurial } \\
\text { process with a resolution, efficiency, } \\
\text { and respect for ethical principles in } \\
\text { different contexts and personal, social, } \\
\text { academic, and work situations, in } \\
\text { order to transform ideas into actions. }\end{array}$ \\
\hline Andalusia & $\begin{array}{l}\text { Jaén University and Sagrada } \\
\text { Familia Professional Centre. } \\
\text { Loyola Andalucía University. }\end{array}$ & $\begin{array}{l}\text { Decree } 97 / 2015 \text {, of March } 3, \\
\text { which establishes the organization } \\
\text { and curriculum of Primary } \\
\text { Education in the Autonomous } \\
\text { Community of Andalusia. }\end{array}$ & $\begin{array}{l}\text { Article 6. Key competences. } \\
\text { (f) Sense of initiative and } \\
\text { entrepreneurial spirit. }\end{array}$ \\
\hline
\end{tabular}


Table 1. Cont.

\begin{tabular}{|c|c|c|c|}
\hline $\begin{array}{l}\text { Autonomous } \\
\text { Community }\end{array}$ & University & Decree & $\begin{array}{l}\text { Entrepreneurial Competence to Be } \\
\text { Developed }\end{array}$ \\
\hline Madrid & $\begin{array}{l}\text { Pontificia Comillas } \\
\text { University. }\end{array}$ & $\begin{array}{l}\text { Decree } 89 / 2014 \text {, of July } 24 \text {, of the } \\
\text { Governing Council, by which the } \\
\text { Primary Education Curriculum is } \\
\text { established for the Community } \\
\text { of Madrid. }\end{array}$ & $\begin{array}{l}\text { Article 5. Competences. } \\
6 \text {. Sense of initiative and } \\
\text { entrepreneurial spirit. } \\
\text { * The students will be able to take } \\
\text { some other area in the block of } \\
\text { subjects of free autonomic } \\
\text { configuration, as is the case of } \\
\text { "Creativity and Entrepreneurship". } \\
\text { The competence called "sense of } \\
\text { entrepreneurship and entrepreneurial } \\
\text { spirit", associated with this area will } \\
\text { be included in the "Creativity and } \\
\text { Entrepreneurship" block of subjects. } \\
\text { Entrepreneurship and creativity, } \\
\text { understood as the ability to build and } \\
\text { transform the circumstances and the } \\
\text { environment in which we live, refer } \\
\text { to a constant exercise of "creating } \\
\text { value" whatever the context: } \\
\text { personal, social, or business. }\end{array}$ \\
\hline Catalonia & Ramón Llull University. & $\begin{array}{l}\text { Decree } 119 / 2015 \text {, of June } 23 \text {, on } \\
\text { the organization of the teaching of } \\
\text { Primary Education. }\end{array}$ & $\begin{array}{l}\text { Article } 6 \text { and Annex 1. Basic } \\
\text { competencies. } \\
\text { 8. Competence of autonomy, personal } \\
\text { initiative, and entrepreneurship. It is } \\
\text { the acquisition of awareness and } \\
\text { application of a set of interrelated } \\
\text { personal values and attitudes, such as } \\
\text { responsibility, perseverance, } \\
\text { self-knowledge and self-esteem, } \\
\text { creativity, self-criticism, emotional } \\
\text { control, the ability to choose, to } \\
\text { imagine projects and to turn ideas } \\
\text { into actions, to learn from mistakes, } \\
\text { to take risks and to work in teams. }\end{array}$ \\
\hline
\end{tabular}

Note: Prepared by the authors.

Moreover, the values that govern the Society of Jesus and its educational institutions reflect authentic leadership based on four fundamental pillars: self-awareness (strengths, weaknesses, and values) and worldview; ingenuity (innovation to adapt to a changing world); love (mutual support, loyalty, affection, working with respect, passion and courage, putting the team above one's own interests); and heroism (effort, tireless energy, willpower, and resilience). Alongside the values, which are closely linked to the EC, there are a number of own competencies of the Jesuit institution, such as: taking risks, making decisions, being flexible, innovating, leading, working amicably in a team, motivating (colleagues), coping with change and adapting, taking initiatives, acting quickly, setting ambitious goals, communicating, persuading, seeing opportunities, observing, being open to new ideas and being quick to act [39].

These values and competencies identify the type of person the Society of Jesus seeks to form through its educational institutions, which, even today, continue to challenge and test entities and individuals through the organization of multinational teams working in harmony, motivating exemplary performances, and remaining 'change-ready' and strategically adaptable [39]. An example of this is the Global Social Benefit Institute (GSBI) which, after sixteen years of helping more than 500 social and environmental entrepreneurs, has been able to validate its methodology based on the values of Ignatian pedagogy [40], 
a pedagogy in which creativity, innovation, and energy, together with a proactive and responsible attitude to life are the hallmarks of a community of entrepreneurs: the Jesuits. Another example is that of Cooke [41], in which several Jesuits give an example of how it is possible to be socially responsible entrepreneurs.

\section{Reference Frameworks on Entrepreneurial Competence: EntreComp, EntreCompEdu, ECI Order}

Since EC became one of the eight key competencies for lifelong learning, efforts have been made to design and develop different reference frameworks for its implementation and assessment. This is the case of EntreComp and EntreCompEdu. Each of them, as well as the ECI Order, is explained below as being of particular relevance to this research.

\subsection{EntreComp}

Different authors have been highlighting for years the need to carry out a good design of EE, transforming curricula, incorporating clear objectives, and modifying teachinglearning methodologies and assessment systems [25,42,43]. Hence, with the intention of promoting a shared vision of EC, the European Commission developed a framework known as EntreComp [42]. It is a way to equip people with a wide range of transversal skills and key competencies such as En, critical thinking, or problem-solving, which open the door to personal fulfillment and development, social inclusion, active citizenship, and employment.

EntreComp is a framework that has been validated through iterative consultations with different stakeholders, consisting of 3 competence areas, 15 competencies, an 8-level progression model, and a comprehensive list of 442 learning outcomes [2,43]. Figure 1 shows how this framework is represented as fractions of a pie chart in which each portion has a different color: blue for the competencies in the Ideas and opportunities area, orange for those in the Resources area, and green for the competencies in the Into action area. All fractions are surrounded by three rings of competence areas, which in turn cover the 15 competencies that are mentioned in Table 4 . This figure only underlines the connection between all competencies and the lack of an ordered and hierarchical classification of competencies [2].

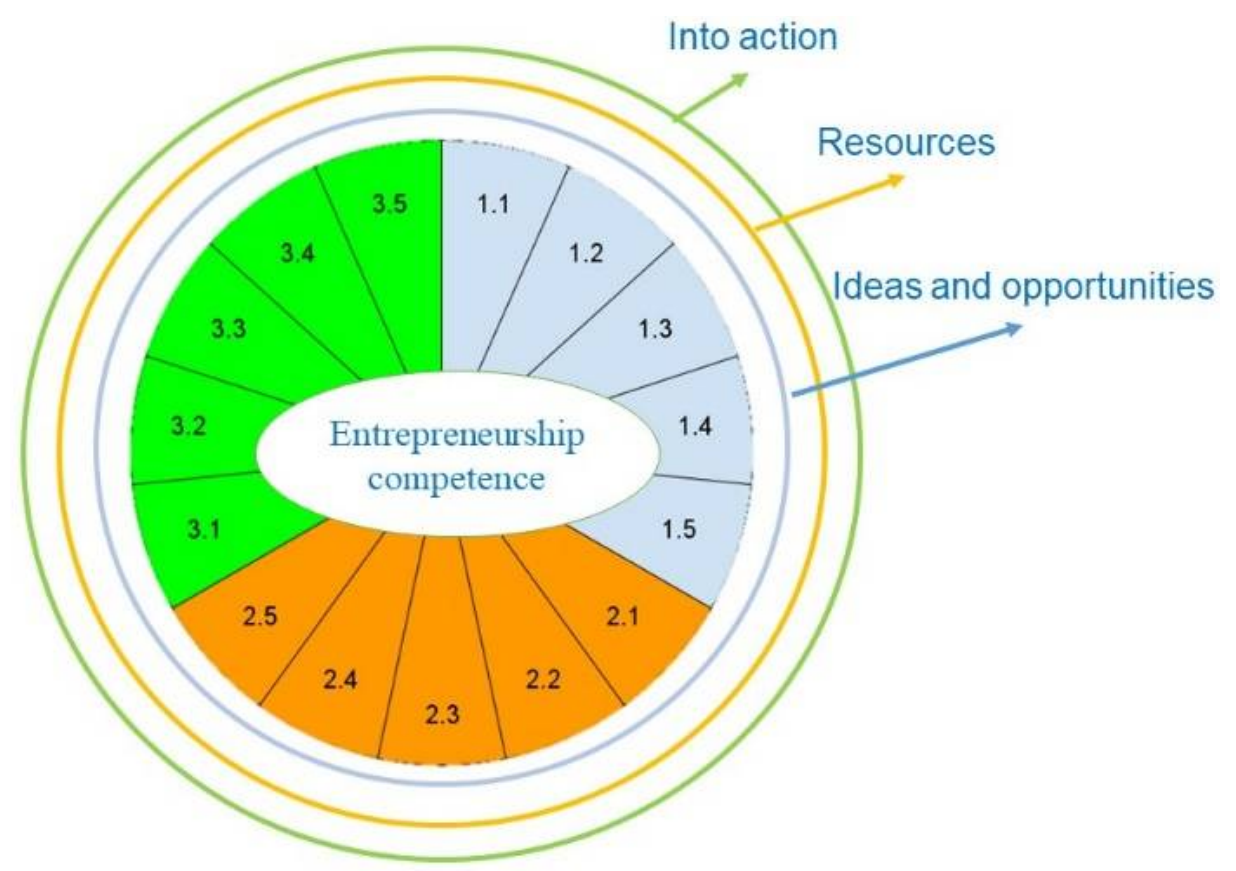

Figure 1. EntreComp competences areas and competencies. Note: Prepared by the authors based on Bacigalupo et al. [2]. 


\subsection{EntreCompEdu}

The EntreCompEdu project, co-funded by the Erasmus+ Programme of the European Union, aims to improve teachers' professional development through a skills framework to understand and improve their entrepreneurial competencies in relation to EE. The aim of this framework is to help shape a creative and entrepreneurial mindset in teachers and to develop a professional framework of entrepreneurial competencies based on the European EntreComp framework. The difference between the two frameworks is that EntreCompEdu focuses on those skills that primary, secondary or vocational teachers can use to facilitate EE in the classroom [11], while EntreComp focuses on the general citizen.

EntreCompEdu is based on six principles according to which knowledge is socially constructed through interaction and experience, and acquired through an iterative process: 1. Educators should facilitate creative thinking throughout the learning process; 2. Educators should seek opportunities in the real world for students to develop and apply their entrepreneurial skills; 3 . Entrepreneurial learning is about creating value for others beyond the school or college; 5 . Encouraging reflection, flexible thinking, and experiential learning; 6. Making entrepreneurial skills an explicit part of learning and assessment [11]. EntreCompEdu competencies areas and competencies are listed in Table 2.

Table 2. EntreCompEdu competences areas and competences.

\begin{tabular}{|c|c|}
\hline Competences Areas & Competences \\
\hline \multirow{3}{*}{$\begin{array}{l}\text { 1. Professional knowledge and understanding of } \\
\text { entrepreneurial education }\end{array}$} & 1.1 Knowing entrepreneurial education \\
\hline & 1.2 Valuing entrepreneurial education \\
\hline & 1.3 Understanding how learners develop entrepreneurial competences \\
\hline \multirow{3}{*}{ 2. Planning } & 2.1 Setting entrepreneurial learning goals that are ethical and sustainable \\
\hline & 2.2 Making connections \\
\hline & 2.3 Creating an empowering entrepreneurial learning environment \\
\hline \multirow{5}{*}{ 3. Teaching and training } & 3.1 Instructing to enthuse and engage \\
\hline & 3.2 Creating value for others \\
\hline & 3.3 Teaching through real-world contexts \\
\hline & 3.4 Encouraging self-awareness and self-confidence to support learning \\
\hline & 3.5 Promoting productive working with others \\
\hline \multirow{3}{*}{ 4. Assessment } & 4.1 Checking and reporting on progress \\
\hline & 4.2 Sharing feedback \\
\hline & 4.3 Recognising progress and achievement \\
\hline \multirow{3}{*}{ 5. Professional Learning } & 5.1 Evaluating impact \\
\hline & 5.2 Researching practice \\
\hline & 5.3 Building and sustaining networks \\
\hline
\end{tabular}

Note: Prepared by the authors based on Grigg [11] and Bantani Education (http:/ / entrecomp.eu) (accessed on 1 May 2021).

\subsection{ECI Order}

In Spain, the profession of primary education teacher is regulated by the ECI Order which requires the possession of the corresponding university degree. Each university must draw up a report for the verification of its degrees, which must contain a number of aspects, including objectives and competencies. As far as competencies are concerned, in Section 3, the ECI Order establishes a minimum of 12 competencies that the primary education degree must include and which reflect the competencies that future teachers must acquire (Table 3). Even so, each university has a range of 30 to 60 ECTS at its disposal to assign the competencies it deems appropriate and to establish the specialization pathways or qualifying mentions it wishes. That should be done in accordance with the provisions of, 
among others, letter b of Article 17 of Organic Law 2/2006, which refers to the EC [36], mentioned before.

Table 3. General competencies of the ECI Order.

1. Know the curricular areas of primary education, the interdisciplinary relationship between them, the evaluation criteria, and the body of didactic knowledge about the respective teaching and learning procedures.

2. Design, plan and evaluate teaching and learning processes, both individually and in collaboration with other teachers and professionals of the center.

3. Effectively deal with language learning situations in multicultural and multilingual contexts. Encourage reading and critical commentary of texts from the various scientific and cultural domains contained in the school curriculum.

4. Design and regulate learning spaces in contexts of diversity and that attend to gender equality, equity, and respect for human rights that shape the values of citizenship formation.

5. Promote coexistence in the classroom and outside it, solve discipline problems, and contribute to the peaceful resolution of conflicts. To stimulate and value effort, perseverance, and personal discipline in students.

6. Know the organization of primary schools and the diversity of actions that comprise its operation. Perform the functions of tutoring and guidance with students and their families, attending to the unique educational needs of students. To assume that the exercise of the teaching function must be perfected and adapted to scientific, pedagogical, and social changes throughout life.

7. Collaborate with the different sectors of the educational community and the social environment. To assume the educational dimension of the teaching function and to promote democratic education for active citizenship.

8. Maintain a critical and autonomous relationship with respect to knowledge, values, and public and private social institutions.

9. Value the individual and collective responsibility in the achievement of a sustainable future.

10. Reflect on classroom practices in order to innovate and improve teaching. Acquire habits and skills for autonomous and cooperative learning and promote it among students.

11. Know and apply information and communication technologies in the classroom. To selectively discern audiovisual information that contributes to learning, civic formation, and cultural richness.

12. Understand the role, possibilities, and limits of education in today's society and the fundamental competencies that affect primary schools and their professionals. To know models of quality improvement with application to educational centers.

Note: Prepared by the authors based on ECI Order [34].

The specific competencies listed in the ECI Order are divided according to the core subjects into basics, didactic and disciplinary training, and practicum. In total, there are 69 competencies. Of the 69,24 correspond to the competencies of basic training subjects distributed as follows: Learning and personality development (6), Educational processes and contexts (13), Society, family, and school (5); 37 to those of Didactic and disciplinary: Teaching and learning of: Experimental Sciences (6), Social Sciences (7), Mathematics (6), Languages (10), Music, Plastic and Visual Education (4) and Physical Education (4); and, 8 to the Practicum (school internships, including the Final Degree Project).

\section{Aims of the Study}

The general objectives of the study are as follows:

1. To compare the competence areas proposed by the European Commission's EC Framework for the citizen (EntreComp) and the EC Framework for the educator (EntreCompEdu) proposed by Bantani Education within the framework of the European Union's Erasmus + program.

2. Based on EntreComp and EntreCompEdu, to analyze the incorporation of EC in the formulation of the competencies of the primary education degrees offered by the 
Spanish Jesuit universities. For this second objective, four more specific objectives are set out:

1.1 Based on EntreComp and EntreCompEdu, to recognize the incorporation of EC in the basic competencies proposed by the Spanish Jesuit universities that offer primary education degrees.

2.1 Based on EntreComp and EntreCompEdu, to recognize the incorporation of $\mathrm{EC}$ in the general competencies proposed by the Spanish Jesuit universities that offer primary education degrees.

3.1 Based on EntreComp and EntreCompEdu, to recognize the incorporation of EC in the transversal competencies proposed by the Spanish Jesuit universities that offer primary education degrees.

4.1 Based on EntreComp and EntreCompEdu, to recognize the incorporation of EC in the specific competencies proposed by Spanish Jesuit universities that offer primary education degrees.

\section{Method}

The methodology followed in this research is qualitative in nature. Our team, made up of three professionals from the field of education closely linked to the EC, carried out a content analysis of the 631 competencies that correspond to the primary education degree offered by the five Spanish Jesuit universities or university centers according to the Registry of Universities, Centres and Degrees of the Ministry of Science, Innovation, and Universities (RUCT). We belong to the field of education, have between 4 and 25 years of experience in the field of education, teaching, and university research, and have participated in national and European projects related to EC.

For data collection, the authors used the ECI Order, the Spanish Jesuit universities offering primary education degrees (universities), the information collected from the EntreComp and EntreCompEdu frameworks and the RUCT. The latter is a tool (public register) created by Royal Decree 1509/2008, of 12 September, which regulates the Register of Universities, Centres and Degrees [44]. Its aim is to provide the most relevant information on the universities, centers, and degrees that make up the Spanish university system, in relation to official Bachelor's, Master's, and Doctoral degrees.

Specifically, the content analysis was carried out in several phases. In the first phase, the following actions were carried out: transferring to an Excel document all the competencies included in the universities offering the primary education degree and registered in the RUCT, for which purpose the authors opened the same amount of worksheets as universities were required (a total of 65 worksheets); reviewing the documents EntreComp, EntreCompEdu and the ECI Order; and comparing the competence areas and competencies of EntreComp (E) and EntreCompEdu (EDU). This phase was carried out between January and February 2021.

In the second phase, which took place from February to May 2021, the 631 competencies (basic -BC-, general -GC-, transversal -TC- and specific -SC-) identified and collected in the RUCT with respect to the selected universities were contrasted with the competencies listed in the ECI Order. Figure 2 shows the distribution of the competencies by selected universities, i.e., the University of Deusto (UD), the University of Jaén, as the institution to which the Sagrada Familia University Centre (Jesuit center) is attached (UJ), Loyola Andalusia University (LAU), Comillas Pontifical University (CPU) and Ramón LLull University (RLLU), as the institution in which various Jesuit centers are integrated. 


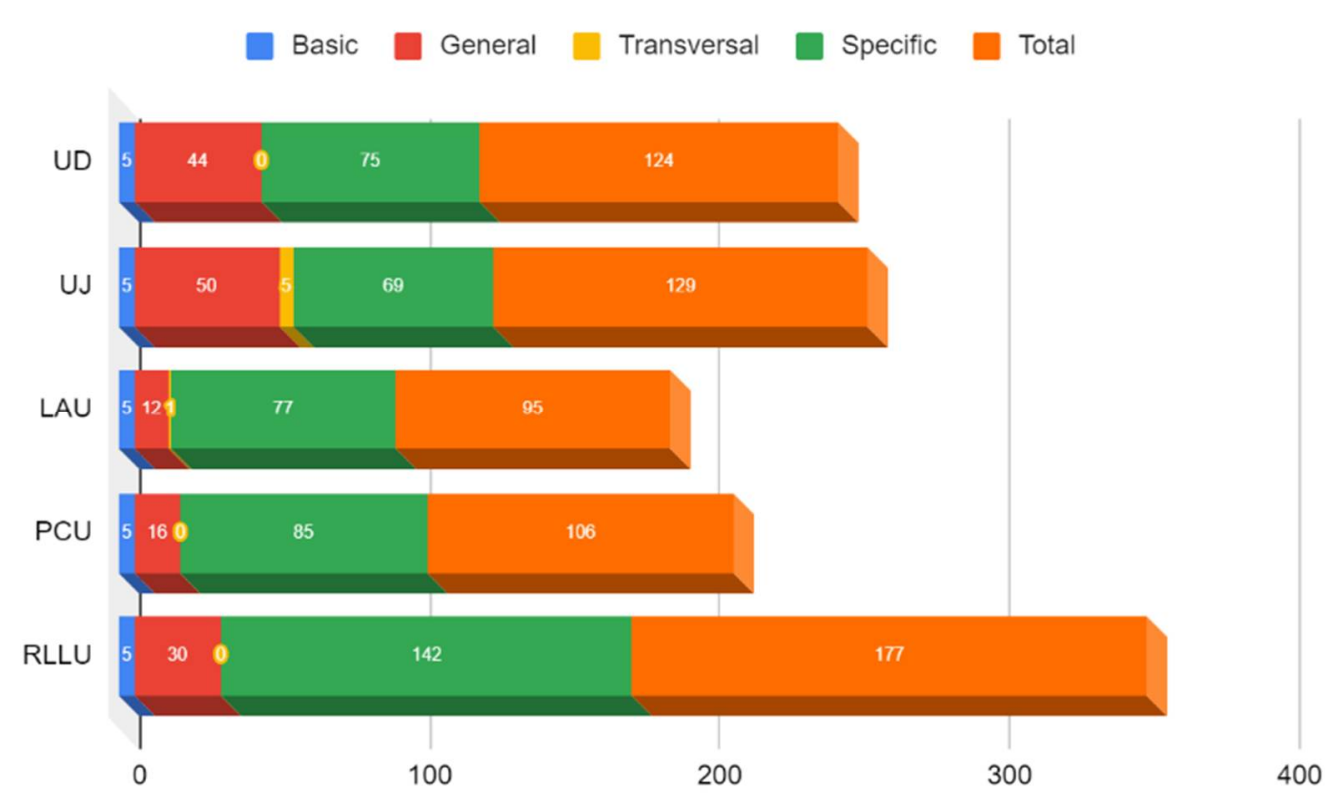

Figure 2. Distribution of analyzed competencies by the university. Note: Prepared by the authors.

The last phase focused on recognizing in detail each of the 631 competencies ( 25 basic, 152 general, 6 transversal, and 448 specific) included in the universities in relation to the competence areas and competencies proposed by $\mathrm{E}$ and EDU.

Following Ruiz Olabuénaga [45], several analyses of the 631 competencies have been carried out systematically and objectively, in a total and complete manner, with the idea of capturing the full meaning of the text. In addition, the manifest content or direct reference has been sought, and on the other hand, the latent content or indirect reference. As Ruiz Olabuénaga [45] points out, direct reference has been considered when the competencies explicitly refer to terms such as planning, management, motivation, creativity, value creation, teamwork, initiative, communication, ethical thinking, sustainability, risks, organization of resources and vision.

Initially, all reviews and analyses were carried out individually, in order to triangulate the data among the three experts until a consensus was reached $[46,47]$ and, in this way, to reduce possible biases in data collection and analysis, to make the study more rigorous and to add more consistency to it [48].

\section{Results}

Once the search using the descriptors "degree" and "social and legal sciences" was concluded for Spanish Jesuit universities offering a primary education degree, and after removing the extinct degrees in the RUCT, the tool yielded a total of 65 universities. Five institutions out of 65 were selected for this study, four Jesuit universities and one that integrates Jesuit centers. The resulting total of competencies to be analyzed was 631 (25 basic, 152 general, 6 transversal, and 448 specific).

With regard to the first objective, Table 4 shows the correspondence between $\mathrm{E}$ and EDU. As can be seen, one of the differences between the two frameworks is the target audience (the former to the general public, and the latter to teachers, specifically primary, secondary, and vocational training teachers). On the other hand, the number of competence areas and competencies is also different. Thus, while $\mathrm{E}$ is divided into three competence areas and fifteen competencies, five per competence area, EDU is divided into five competence areas and seventeen competencies, three per competence area except for the third competence area (Teaching and training) which has five. Furthermore, according to Bantani Education, competence E2.5 (Mobilising others) and competence area 1 as a whole (Professional knowledge and understanding of EE), which is a new EDU area introduced by Bantani Education, do not correspond to any EDU and E areas respectively. 
Table 4. Comparing EntreComp (E) and EntreCompEdu (EDU).

\begin{tabular}{|c|c|c|c|}
\hline \multicolumn{2}{|c|}{ EntreComp } & \multicolumn{2}{|c|}{ EntreCompEdu } \\
\hline Competences areas & Competences & Competences & Competences areas \\
\hline \multirow{5}{*}{ Ideas and opportunities } & 1.1. Spotting opportunities & 2.2 Making connections & 2. Planning \\
\hline & 1.2 Creativity & 3.2 Creating value for others & 3. Teaching and training \\
\hline & 1.3. Vision & $\begin{array}{l}\text { 2.1 Setting entrepreneurial } \\
\text { learning goals that are ethical } \\
\text { and tsustainable }\end{array}$ & 2. Planning \\
\hline & 1.4 Valuing ideas & $\begin{array}{l}4.3 \text { Recognising progress } \\
\text { and achievement }\end{array}$ & 4. Assessment \\
\hline & 1.5 Ethical and sustainable thinking & $\begin{array}{l}\text { 2.1 Setting entrepreneurial } \\
\text { learning goals that are ethical } \\
\text { and sustainable }\end{array}$ & 2. Planning \\
\hline \multirow{5}{*}{ Resources } & 2.1 Self-awareness and self-efficacy & $\begin{array}{l}\text { 3.4 Encouraging self-awareness } \\
\text { and self-confidence to } \\
\text { support learning } \\
\text { 4.2 Sharing feedback } \\
\text { 4.3 Recognising progress } \\
\text { and achievement }\end{array}$ & $\begin{array}{l}\text { 3. Teaching and training } \\
\text { 4. Assessment }\end{array}$ \\
\hline & 2.2 Motivation and perseverance & $\begin{array}{l}3.1 \text { Instructing to enthuse } \\
\text { and engage }\end{array}$ & 3. Teaching and training \\
\hline & 2.3 Mobilising resources & $\begin{array}{l}\text { 2.3 Creating an empowering } \\
\text { entrepreneurial } \\
\text { learning environment }\end{array}$ & 2. Planning \\
\hline & 2.4 Financial and economic literacy & $\begin{array}{l}3.3 \text { Teaching through real-world } \\
\text { contexts }\end{array}$ & 3. Teaching and training \\
\hline & 2.5. Mobilising others & & \\
\hline \multirow{5}{*}{ Into action } & 3.1 Taking the initiative & $\begin{array}{l}\text { 2.3 Creating an empowering } \\
\text { entrepreneurial learning } \\
\text { environment }\end{array}$ & 2. Planning \\
\hline & 3.2. Planning and management & $\begin{array}{l}\text { 2.1 Setting entrepreneurial } \\
\text { learning goals that are ethical } \\
\text { and sustainable }\end{array}$ & 2. Planning \\
\hline & $\begin{array}{l}3.3 \text { Coping with uncertainty, } \\
\text { ambiguity and risk }\end{array}$ & $\begin{array}{l}\text { 2.3 Creating an empowering } \\
\text { entrepreneurial learning } \\
\text { environment } \\
\text { 3.4 Encouraging self-awareness } \\
\text { and self-confidence to } \\
\text { support learning }\end{array}$ & $\begin{array}{l}\text { 2. Planning } \\
\text { 3. Teaching and training }\end{array}$ \\
\hline & 3.4 Working with others & $\begin{array}{l}\text { 3.5 Promoting productive } \\
\text { working with others } \\
5.3 \text { Building and } \\
\text { sustaining networks }\end{array}$ & $\begin{array}{l}\text { 3. Teaching and training } \\
\text { 5. Professional learning }\end{array}$ \\
\hline & 3.5 Learning through experience & $\begin{array}{l}\text { 4.1 Checking and reporting } \\
\text { on progress } \\
\text { 4.2 Sharing feedback } \\
\text { 5.1 Evaluating impact } \\
5.2 \text { Researching practice }\end{array}$ & $\begin{array}{l}\text { 4. Assessment } \\
\text { 5. Professional learning }\end{array}$ \\
\hline
\end{tabular}


With regard to the first specific objective, of the five basic competencies that are repeated in all the universities, two of them recognize the incorporation of E competencies and there are no EDU competencies.

With regard to the second specific objective, with the exception of CPU, eight of the 12 general competencies listed in the ECI Order are repeated in the rest of the universities, in which E and EDU competencies are recognized. In the case of CPU, in the five general competencies that are presented in the RUCT, the incorporation of E and EDU competencies is recognized. In addition, more general competencies are recognized in three other universities: seven in the case of UD; four in the case of UJ; and ten in the case of RLLU.

In relation to the third specific objective, only two of the universities, UJ and LAU, include in the RUCT transversal competencies in which the incorporation of E and EDU competencies is recognized. In the case of $\mathrm{UJ}$, we must refer to five competencies and in the case of LAU to one competence.

As far as the fourth specific objective is concerned, with the exception of UD, the rest of the universities repeat thirteen specific competencies in which the incorporation of $E$ and EDU competencies is recognized and which correspond to some of the 69 specific competencies listed in the ECI Order. In addition, more specific competencies are recognized in three other universities: thirty-nine in UD, three in LAU, seven in CPU, and sixteen in RLLU.

All these data are reflected in Tables 5 and 6. In Table 5 we can see the number, percentage, and distribution of competencies proposed by the five universities according to the RUCT (RUCT competencies) and regarding the type of competencies and university in which the incorporation of E and EDU competencies is recognized. In Table 6, this distribution is established according to the E and EDU competencies recognized and the number of times they have been recognized.

As can be seen in Table 5, LAU and RLLU stand out for being the ones that incorporate the highest percentage of E and EDU competencies in their GC, and UD as far as SC are concerned. On an overall level, UD and RLLU incorporate the highest percentage of E and EDU competencies.

The analysis carried out allows us to conclude that, as we can see in Table 6, with the exception of EDU, 4 competence areas (Assessment), the rest of the E and EDU competence areas are included in the RUCT competencies. However, it is noteworthy that the three E competence areas are the ones in which these RUCT competencies are most frequently recognized.

However, if we pay attention to each of the E and EDU competencies, Table 6 shows that the following E and EDU competencies are not recognized in the RUCT competencies: E2.2 (Motivation and perseverance), E2.4 (Financial and economic literacy), E3.3 (Coping with uncertainty, ambiguity, and risk), EDU4.1 (Checking and reporting on progress), EDU4.2 (Sharing feedback), and EDU4.3 (Recognising progress and achievement). On the other hand, the competencies that stand out the most include E2.5 (Mobilising others), E3.2 (Planning and management), E3.4 (Working with others), and EDU 2.3 (Creating an empowering entrepreneurial learning environment).

Table 5. Number, percentages, and distribution of Registry of Universities, Centres, and Degrees of the Ministry of Science, Innovation, and Universities (RUCT) competencies according to the type of competencies and university, in which E and EDU competencies are recognized.

\begin{tabular}{ccccccc}
\hline & UD & UJ & LAU & PCU & RLLU & Total Sum \\
\hline BC & $2 / 5(40 \%)$ & $2 / 5(40 \%)$ & $2 / 5(40 \%)$ & $2 / 5(40 \%)$ & $2 / 5(40 \%)$ & 10 \\
\hline GC & $15 / 44(34 \%)$ & $12 / 50(24 \%)$ & $8 / 12(66,6 \%)$ & $5 / 16(31,2 \%)$ & $18 / 20(60 \%)$ & 58 \\
\hline TC & $0(0 \%)$ & $5 / 5(100 \%)$ & $1 / 1(100 \%)$ & $0(0 \%)$ & $0(0 \%)$ & 6 \\
\hline SC & $39 / 75(52 \%)$ & $13 / 69(18,8 \%)$ & $16 / 71(22,5 \%)$ & $20 / 85(23,5 \%)$ & $29 / 42(20,4 \%)$ & 117 \\
\hline & $56(29,3 \%)$ & $32(16,7 \%)$ & $27(14,1 \%)$ & $27(14,3 \%)$ & $49(25,6 \%)$ & $191(30 \%)$ \\
\hline
\end{tabular}


Table 6. Number of occasions in which E and EDU competencies are recognized in RUCT competencies.

\begin{tabular}{|c|c|c|c|c|c|c|c|c|c|c|c|c|c|c|c|c|c|c|c|c|}
\hline & & BC & & & & & & & & TC & & & & & & & & & TO & TAL \\
\hline & & $\mathrm{C}$ & $\mathrm{C}$ & 1 & 2 & 4 & 5 & $\mathrm{~T}$ & 2 & 3 & $\mathrm{~T}$ & $C$ & 1 & 2 & 3 & 4 & 5 & $\mathrm{~T}$ & & \\
\hline \multirow{15}{*}{$\begin{array}{l}\text { EntreComp } \\
\quad(222)\end{array}$} & \multirow{5}{*}{1} & E1.1 & & & & & & 0 & 1 & & 1 & & & & & & & 0 & 1 & \multirow{5}{*}{57} \\
\hline & & E1.2 & 4 & 1 & & & & 5 & 1 & & 1 & & 1 & & & 1 & 1 & 3 & 9 & \\
\hline & & E1.3 5 & 12 & 1 & & & & 13 & 1 & & 1 & 4 & 2 & & & 1 & & 7 & 26 & \\
\hline & & E1.4 & 4 & & & & & 4 & 1 & & 1 & & & & & & & 0 & 5 & \\
\hline & & E1.5 & 4 & 1 & & 1 & & 6 & 1 & 1 & 2 & 4 & 3 & & & & 1 & 8 & 16 & \\
\hline & \multirow{5}{*}{2} & E2.1 & & & & & 1 & 1 & & & 0 & & 1 & & & 1 & & 2 & 3 & \multirow{5}{*}{72} \\
\hline & & E2.2 & & & & & & 0 & & & 0 & & & & & & & 0 & 0 & \\
\hline & & E2.3 & 4 & 1 & 1 & & & 6 & 1 & & 1 & 4 & 5 & & 3 & 2 & 2 & 16 & 23 & \\
\hline & & E2.4 & & & & & & 0 & & & 0 & & & & & & & 0 & 0 & \\
\hline & & E2.5 5 & & 3 & 3 & 2 & 1 & 9 & 1 & & 1 & 12 & 14 & & & & 5 & 31 & 46 & \\
\hline & \multirow{5}{*}{3} & E3.1 & & 1 & & & 1 & 2 & & & 0 & 4 & 1 & & & & & 5 & 7 & \multirow{5}{*}{93} \\
\hline & & E3.2 & 4 & & & 1 & 2 & 7 & & & 0 & 8 & 16 & & & 1 & 1 & 26 & 33 & \\
\hline & & E3.3 & & & & & & 0 & & & 0 & & & & & & & 0 & 0 & \\
\hline & & E3.4 & 12 & 2 & & 1 & 3 & 18 & 1 & & 1 & 12 & 9 & & & 1 & 3 & 25 & 44 & \\
\hline & & E3.5 & & 1 & & & 2 & 3 & & & 0 & 4 & 1 & & & 1 & & 6 & 9 & \\
\hline \multirow{17}{*}{$\begin{array}{c}\text { EntreCompEdu } \\
(138)\end{array}$} & \multirow{3}{*}{1} & EDU1.1 & 4 & & & & & 4 & & & 0 & 4 & & & & & & 4 & 8 & \multirow{3}{*}{20} \\
\hline & & EDU1.2 & 4 & & & & & 4 & & & 0 & 4 & & & & & & 4 & 8 & \\
\hline & & EDU1.3 & & & & & & 0 & & & 0 & 4 & & & & & & 4 & 4 & \\
\hline & \multirow{3}{*}{2} & EDU2.1 & 4 & 1 & & & & 5 & 1 & 1 & 2 & & 4 & & 1 & & 2 & 7 & 14 & \multirow{3}{*}{48} \\
\hline & & EDU2.2 & & & & & & 0 & & & 0 & & 2 & & & & 2 & 4 & 4 & \\
\hline & & EDU2.3 & 8 & 1 & 1 & & & 10 & 1 & & 1 & 4 & 6 & & 3 & 2 & 4 & 19 & 30 & \\
\hline & \multirow{5}{*}{3} & EDU3.1 & 4 & & & & & 4 & & & 0 & & & & & & & 0 & 4 & \multirow{5}{*}{34} \\
\hline & & EDU3.2 & & 1 & & & & 1 & & & 0 & & & & & & & 0 & 1 & \\
\hline & & EDU3.3 & & & & & & 0 & & & 0 & & 3 & & & & & 3 & 3 & \\
\hline & & EDU3.4 & & & & & 2 & 2 & & & 0 & & 1 & & & 1 & 1 & 3 & 5 & \\
\hline & & EDU3.5 & 8 & 2 & & 1 & 3 & 14 & & & 0 & 4 & 3 & & & & & 7 & 21 & \\
\hline & \multirow{3}{*}{4} & EDU4.1 & & & & & & 0 & & & 0 & & & & & & & 0 & 0 & \multirow{3}{*}{0} \\
\hline & & EDU4.2 & & & & & & 0 & & & 0 & & & & & & & 0 & 0 & \\
\hline & & EDU4.3 & & & & & & 0 & & & 0 & & & & & & & 0 & 0 & \\
\hline & \multirow{3}{*}{5} & EDU5.1 & 4 & & & & & 4 & 1 & & 1 & & 4 & & & & & 4 & 9 & \multirow{3}{*}{36} \\
\hline & & EDU5.2 & & 1 & & & & 1 & 1 & & 1 & & 4 & & & & & 4 & 6 & \\
\hline & & EDU5.3 & 4 & 1 & & & & 5 & 2 & & 2 & 4 & 6 & & & 1 & 3 & 14 & 21 & \\
\hline
\end{tabular}

Note: Prepared by the authors. 1: UD; 2: UJ; 3: LAU; 4: PCU; and 5: RLLU. C: Common; T: Total sum.

On the other hand, if we limit ourselves to each university analyzed, Figure 3 shows that, according to the type of competencies (BC, GC, TC, and SC) provided by the RUCT, those that stand out most, as they are the ones in which the $\mathrm{E}$ and EDU competencies are most frequently recognized, are the SC of UD, followed by the SC of RLLU, the GC of UD and, lastly, the GC of RLLU. 


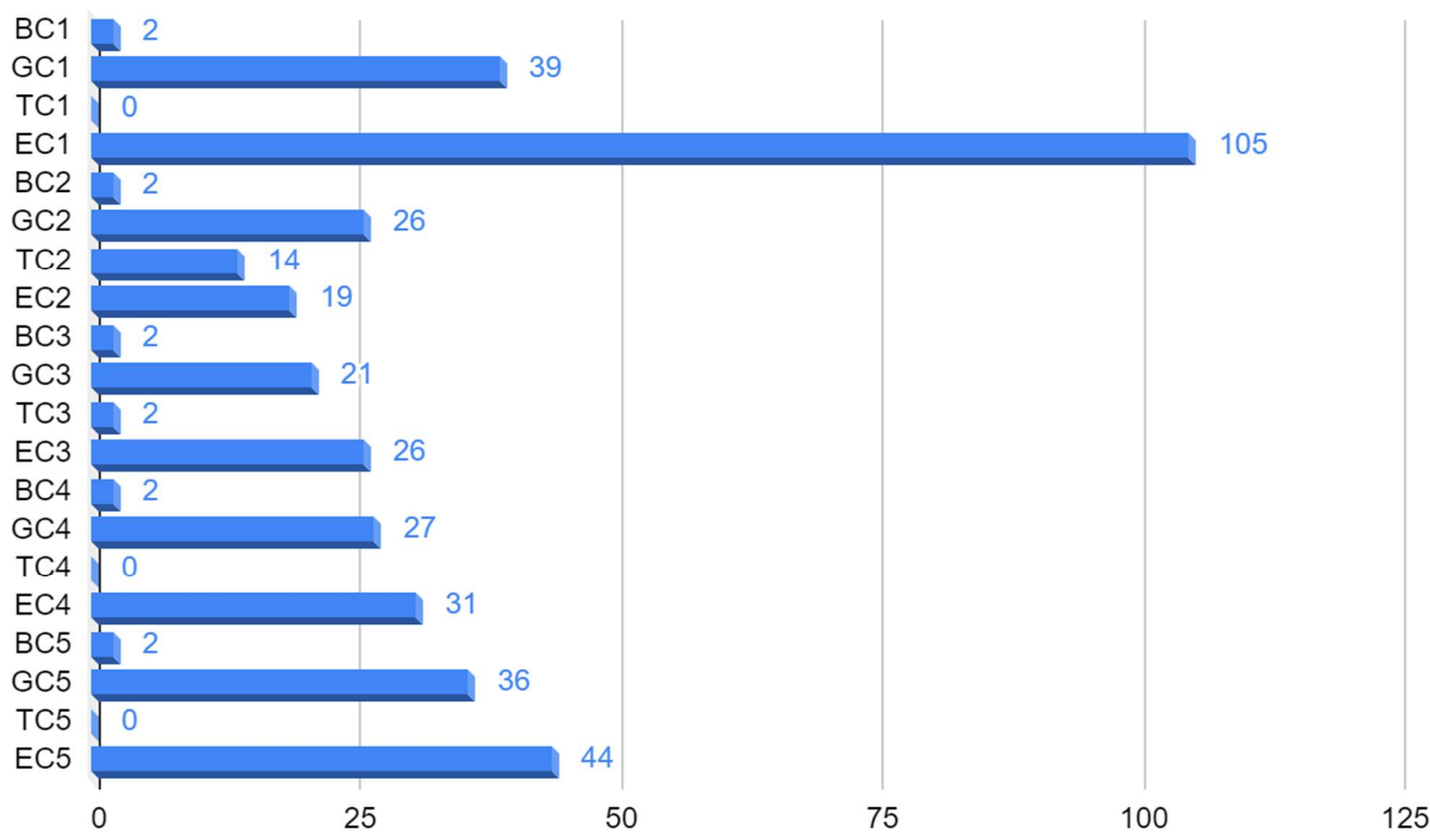

Figure 3. Distribution of type of RUCT competencies where E and EDU competencies are recognized. Note: Prepared by the authors. 1: UD; 2: UJ; 3: LAU; 4: PCU; and 5: RLLU.

Finally, regarding the type of competencies (BC, GC, TC, and SC) provided by the RUCT and to each of the resulting E and EDU competencies, in Table 6 and Figure 4, it can be seen that it is mainly in the TC and GC that the incorporation of the competences E2.5 (Mobilising others), E3.2 (Planning and management), and E3.4 (Working with others), and EDU2.3 (Creating an empowering entrepreneurial learning environment), and E3.5 (Learning through experience) respectively.

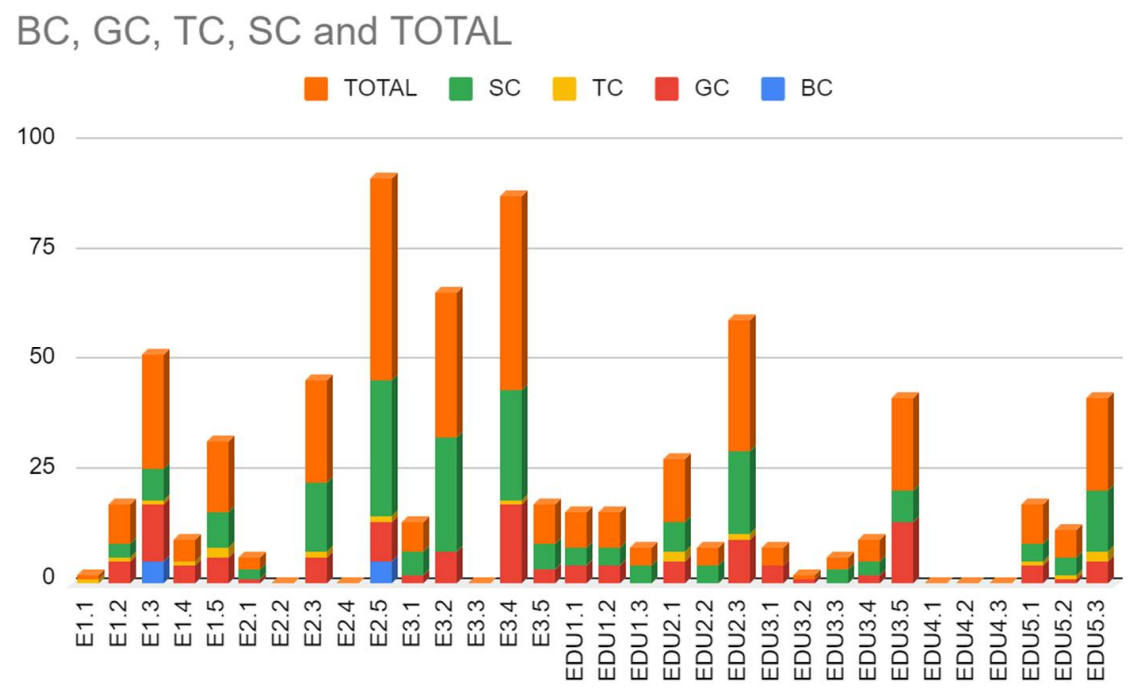

Figure 4. Distribution of E and EDU competencies based on RUCT competencies. Note: Prepared by the authors.

\section{Discussion}

Initial teacher education in Spain is, through the primary education degree, a regulated profession and as such must meet certain minimum requirements, including the competencies to be developed and the structure of the syllabus to be followed. The ECI Order of 2007 regulates this profession. 
The E and EDU competence frameworks contrasted in this study, which include the competence areas and entrepreneurial competencies, were published in 2016 and 2020 respectively. This difference in years between the ECI Order and the EntreComp and EntreCompEdu frameworks have not been a problem when it comes to recognizing competence areas or competencies from both European frameworks listed in the RUCT competencies. In fact, with the exception of competence area 4 of EntreCompEdu, which refers to assessment, the remaining competence areas of both frameworks are included in $30 \%$ of the RUCT competencies, that is, in 191 out of the 631 competencies proposed by the five Spanish Jesuit universities, without considering the repeated competences.

With regard to the correspondence between the two European frameworks, according to Bantani Education, competence E2.5 (Mobilising others) and competence area 1 of EDU as a whole (Professional knowledge and understanding of the EE) do not correspond to any EDU and E competencies respectively. Not in vain, EDU competence area 1 was included by Bantani as a new one.

In any case, it should be noted that the analysis has been carried out without taking into account the correspondence between the two frameworks, in other words, considering all the E and EDU competencies.

Moreover, it should be noted that the competence Mobilising others (E2.5), together with Planning and management (E3.2) and Working with others (E3.4), as well as Creating an empowering entrepreneurial learning environment (EDU2.3) are the most frequently recognized among the RUCT competences. Not by accident, communication and teamwork are two of the main competencies identified in different studies on entrepreneurship [49].

The same applies regarding Planning and management competence. In addition to being one of the entrepreneurial competencies, this is considered a traditional area of initial teacher education. In fact, this is one of the reasons why different studies show that teachers self-perceived better as far as planning competence is concerned. The fact is that primary education degree includes planning and design of general didactics and the didactics of the different curricular subjects (mathematics; social sciences; languages; music, plastic and visual education; physical education; and experimental sciences) in the study plan proposal. Moreover, planning is often a generic instrumental competence integrated into higher education curricula since the Bologna Declaration [50].

Attention is especially drawn to the lack of competencies related to such an important and crucial area as assessment, especially when this refers to checking and reporting progress, sharing feedback, and recognizing progress and achievement. The assessment covered by the RUCT competencies is more oriented towards knowing and selecting assessment criteria, assessing innovation projects, formulating learning outcomes, assessing content in different areas of the curriculum, or identifying and developing tutoring functions.

On the other hand, of the two European En frameworks, the competence areas of EntreComp are the ones that are incorporated to a greater extent in the different RUCT competencies. The fact that EntreCompEdu is in the process of development and implementation may be one of the reasons why its competence areas are reflected to a lesser extent in the RUCT competencies.

Another striking feature is the fact that none of the universities analyzed incorporate the competencies Motivation and perseverance (E2.2), Financial and economic literacy (E2.4), and Coping with uncertainty, ambiguity, and risk (E3.3), in addition to the competencies of EDU area 4 (Assessment) listed above, i.e., Checking and reporting progress (EDU4.1), Sharing feedback (EDU4.2), and Recognising progress and achievement (EDU4.3). These data do not match the studies that establish motivation, perseverance, or coping with uncertainty as characteristics of entrepreneurship and entrepreneurs such as teacherpreneurs $[2,11,15,51,52]$. We cannot forget either that these are inherent to Jesuit universities.

As for the type of competencies, it is in the specific and general competencies of UD and RLLU that the competences Mobilising others (E2.5), Planning and management (E3.2), Working with others (E3.4), and Learning through experience (E3.5), and Creating an empowering entrepreneurial learning environment (EDU2.3) are most frequently recognized. 
This is not particularly surprising, especially if we consider the fact that SCs focus more on subject areas. Moreover, this reflects the importance of these competencies for the professional profile of teachers.

Finally, regarding TCs, it should be added that the lack of this type of competence in three of the five universities analyzed does not mean that they do not exist. In fact, at the moment, for example, the UD is in a working process, defining the TCs, including entrepreneurship, creativity, and innovation.

\section{Conclusions}

Having EE frameworks as EntreComp and EntreCompEdu is essential in order to take further steps and move forward in this field especially when we are dealing with a scenario such as the training of competent teachers for future generations. From an educational perspective, it means that first of all, it is fundamental to embed the EC into the different educational plans and programs. This could make easier and clearer the planning processes from the very beginning. In the case of the Spanish Jesuit universities which offer degrees to train future teachers, this should be a clear advantage. In fact, those universities promote and defend principles, values, and competencies linked to the EC and as such, this should be reflected in the official reference documents (degrees) and in the specific actions to be developed by educators. It is not what always happens.

The results achieved in this study allow us to conclude that, although there is still a long way to go, EC is present in the initial teacher training of the primary education degree. It is clear that this study has its limitations. Thus, for example, it has focused mainly on the competencies to be developed, without delving into other elements of educational planning that could also contribute to the development of EC guided by the European framework EntreCompEdu. This is the case of the use of active and interactive methodologies considered appropriate for EE [53], and the case of the use of authentic assessment systems and models aligned with the competence-based learning and EC. We are convinced that the use of active methodologies, innovative and diverse didactic strategies and authentic assessment systems will contribute to the further development of EC.

In this line, as future research, we believe that a more detailed study of primary education degrees from the methodologies and assessment systems used could give us a more realistic view of EC education and training through this degree. Likewise, an analysis of the incorporation or not of EC in the rest of the Spanish universities and international universities would give us a broader overview of the importance of this competence and to what extent EC is considered a key aspect in the training process of pre-service teachers. Other future research could be the assessment of renewed study plans proposals and their implementation in the light of EntreCompEdu. We assure you that this is not the end, it is just the beginning.

Author Contributions: Conceptualization, A.A.; methodology, A.A., C.M. and E.B.; formal analysis and investigation, A.A., C.M. and E.B.; writing-original draft preparation, A.A.; writing-review and editing, A.A., C.M. and E.B.; supervision, A.A. All authors have read and agreed to the published version of the manuscript.

Funding: This research received no external funding.

Institutional Review Board Statement: Not applicable.

Informed Consent Statement: Not applicable.

Conflicts of Interest: The authors declare no conflict of interest.

\section{References}

1. Commission of the European Communities. Green Paper Entrepreneurship in Europe; European Commission: Brussels, Belgium, 2003.

2. Bacigalupo, M.; Kampylis, P.; Punie, Y.; Van den Brande, G. EntreComp: The Entrepreneurship Competence Framezork; Publication Office of the European Union: Luxembourg, 2016. 
3. Bughin, J.; Hazan, E.; Lund, S.; Dahlstrom, P.; Wiesinger, A.; Subramaniam, A. Skill Shift. Automation and the Future of the Workforce; McKinsey Global: San Francisco, CA, USA, 2018.

4. Comisión Europea. La Iniciativa Emprendedora en la Enseñanza Superior, Especialmente en Estudios no Empresariales; Comisión Europea: Brussels, Belgium, 2008.

5. Comisión Europea. Entrepreneurship Education: Enabling Teachers as a Critical Success Factor; European Commission: Brussels, Belgium, 2011.

6. Comisión Europea. Plan de Acción sobre Emprendimiento 2020: Relanzar el Espíritu Emprendedor en Europa; Comisión Europea: Brussels, Belgium, 2013.

7. Comisión Europea. Educación en Emprendimiento. Guía del Educador, Unidad «Emprendimiento 2020»; Comisión Europea: Brussels, Belgium, 2014.

8. Comisión Europea. Entrepreneurship Education: A Road to Success; European Commission: Brussels, Belgium, 2015.

9. Comisión Europea. Agenda de Capacidades Europea para la Competitividad Sostenible, la Equidad Social y la Resiliencia; Comisión Europea: Brussels, Belgium, 2020.

10. Fayolle, A.; Kariv, D.; Matlay, H. (Eds.) The Role and Impact of Entrepreneurship Education: Contextual Perspectives; Edward Elgar: Cheltenham, UK, 2019.

11. Grigg, R. EntreCompEdu, a professional development framework for entrepreneurial education. Educ. Train. 2020. [CrossRef]

12. Henry, C.; Lewis, K. A review of entrepreneurship education research. Educ. Train. 2018, 60, 263-286. [CrossRef]

13. Lackeus, M. Entrepreneurship in Education. What, Why, When, How; OECD: Paris, France, 2015.

14. Boldureanu, G.; Ionescu, A.M.; Bercu, A.M. Entrepreneurship Education through Successful Entrepreneurial Models in Higher Education Institutions. Sustainability 2020, 12, 1267. [CrossRef]

15. Hameed, I.; Irfan, Z. Entrepreneurship education: A review of challenges, characteristics and opportunities. Entrep. Educ. 2019, 2, 135-148. [CrossRef]

16. Isa, A.S. Teachers' perception on the significance of entrepreneurship educational as a tool for youth empowerment. Int. J. Sci. Res. Multidiscip. Stud. 2019, 5, 66-73.

17. Sadewo, Y.D. The Effect of Learning Outcomes in Entrepreneurship Education Programs of Interest in Entrepreneurship. In Proceedings of the 3rd International Conference on Economics Education and Entrepreneurship, Batam, Indonesia, 28-31 August 2018.

18. Sam, C.; van der Sijde, P. Understanding the concept of the entrepreneurial university from the perspective of higher education models. High. Educ. 2014, 68, 891-908. [CrossRef]

19. Saraiva, H.; Paiva, T. Entrepreneurship Education: Background and Future. In Handbook of Research on Approaches to Alternative Entrepreneurship Opportunities; Leitão, J.G., Cagica, L., Eds.; IGI Global: Hershey, PA, USA, 2020; pp. 1-12.

20. Von Graevenitz, G.; Harhoff, D.; Weber, R. The effects of entrepreneurship education. J. Econ. Behav. Organ. 2010, 76, 90-112. [CrossRef]

21. Welsh, D.H.B.; Tullar, W.L.; Nemati, H. Entrepreneurship education: Process, method, or both? J. Innov. Knowl. $2016,1,125-132$. [CrossRef]

22. The European Parliament and the Council of the European Union. Recommendation of the European Parliament and of the Council on Key Competences for Lifelong Learning; Official Journal of the European Union: Luxembourg, 2006.

23. European Commission/EACEA/Eurydice. Entrepreneurship Education at School in Europe; Eurydice Report; Publications Office of the European Union: Luxembourg, 2006.

24. Deveci, I.; Seikkula-Leino, J. A review of entrepreneurship education in teacher education. Malays. J. Learn. Instr. 2018, 15, 105-148. [CrossRef]

25. Comisión Europea. Una Nueva Agenda de Capacidades para Europa. Trabajar Juntos para Reforzar el Capital Humano, la Empleabilidad y la Competitividad; Comisión Europea: Brussels, Belgium, 2016.

26. Paiva, T.; Alves, M.L.; Sampaio, J.H. Entrepreneurship Education: Background and Future. In Global Considerations in Entrepreneurship Education and Training; Cagica, L., Dias, A., Eds.; IGI Global: Hershey, PA, USA, 2019; pp. 151-161.

27. Wibowo, A.; Saptono, A.; Suparno, S. Does Teachers' Creativity Impact on Vocational Students' Entrepreneurial Intention? J. Entrep. Educ. 2018, 21, 1-12.

28. Suska, M. Entrepreneurial studies in higher education: Some insights for Entrepreneurship education in Europe. Horyz. Polityki 2018, 9, 143-156.

29. Atmojo, I.R.W.; Sajidan, S.; Sunarno, W.; Ashadi, A. Improving the Entrepreneurship Competence of Pre-Service Elementary Teachers on Professional Education Program through the Skills of Disruptive Innovators. Elem. Educ. Online 2019, 18, 1186-1194.

30. Galvão, A.; Ferreira, J.J.; Marques, C. Entrepreneurship education and training as facilitators of regional development: A systematic literature review. J. Small Bus. Enterp. Dev. 2018, 25, 17-40. [CrossRef]

31. Zangeneh, H.; Kavousi, A.; Bahrami, Z. Teachers' Attitudes toward Teaching-Learning Methods of Entrepreneurship Education in Elementary Education. Educ. Strateg. Med Sci. 2020, 12, 1-7.

32. Ministerio de Educación, Cultura y Deporte. La educación Para el Emprendimiento en el Sistema Educativo Español. 2015. RediE. Available online: https:/ / sede.educacion.gob.es/publiventa/d/20842/19/0 (accessed on 6 July 2021).

33. Arruti, A.; Paños-Castro, J. Análisis de las menciones del grado de educación primaria desde la perspectiva de la competencia emprendedora. Rev. Complut. Educ. 2019, 30, 17-33. [CrossRef] 
34. Orden ECI/3857/2007, de 27 de Diciembre, Por la Que se Establecen Los Requisitos Para la Verificación de los Títulos Universitarios Oficiales Que Habiliten Para el Ejercicio de la Profesión de Maestro en Educación Primaria. Boletín Oficial del Estado, 29 de diciembre de 2007. Volume 312, pp. 53747-53750. Available online: https://www.boe.es/boe/dias/2007/12/29/pdfs/A53747-53750.pdf (accessed on 6 July 2021).

35. Ley Orgánica 3/2020, de 29 de Diciembre, por la que se Modifica la Ley Orgánica 2/2006, de 3 de mayo, de Educación. Boletín Oficial del Estado, 30 de Diciembre de 2010. Volume 314, pp. 122868-122953. Available online: https://www.boe.es/boe/dias/ 2020/12/30/pdfs / BOE-A-2020-17264.pdf (accessed on 6 July 2021).

36. Ley Orgánica 8/2013, de 9 de Diciembre, Para la Mejora de la Calidad Educativa. Boletín Oficial del Estado, 10 de Diciembre de 2013. Volume 295, pp. 1-64. Available online: https:/ / www.boe.es/buscar/pdf/2013/BOE-A-2013-12886-consolidado.pdf (accessed on 6 July 2021).

37. Penaluna, A.; Penaluna, K.; Polenakovikj, R. Developing entrepreneurial education in national school curricula: Lessons from North Macedonia and Wales. Entrep. Educ. 2020, 3, 245-263. [CrossRef]

38. Guibert, J.M. Para Comprender la Pedagogía Ignaciana; Ediciones Mensajero: Bilbao, Spain, 2020.

39. Lowney, C. El Liderazgo al Estilo de los Jesuitas; Granica: Barcelona, Spain, 2007.

40. Douglass Warner, K.; Lieberman, A.; Roussos, P. Ignatian Pedagogy for Social Entrepreneurship: Twelve Years Helping 500 Social and Environmental Entrepreneurs Validates the GSBI Methodology. J. Technol. Manag. Innov. 2016, 11, 80-85. [CrossRef]

41. Cooke, P.; Zhiyuan, W.; Domfang, M.C.; Okoh, M.; Bossou, C. The Power of Purpose: Jesuits for Social Entrepreneurship; Santa Clara University, Miller Center for Social Entrepreneurship: Santa Clara, CA, USA, 2016.

42. European Union. EntreComp: The European Entrepreneurship Competence Framework; Publications Office of the European Union: Luxembourg, 2018.

43. McCallum, E.; Weicht, R.; McMullan, L.; Price, A. EntreComp into Action-Get Inspired, Make It Happen: A User Guide to the European Entrepreneurship Competence Framework; Office for Official Publications of the European Union: Luxemburg, 2018.

44. Real Decreto 1509/2008, de 12 de Septiembre, Por el Que se Regula el Registro de Universidades, Centros y Títulos. Boletín Oficial del Estado, 25 de Septiembre de 2008. Volume 232, pp. 38854-38857. Available online: https://www.boe.es/eli/es/rd/2008/09/12/1509/ dof/spa/pdf (accessed on 6 July 2021).

45. Ruiz Olabuénaga, J.I. Teoría y Práctica de la Investigación Cualitativa; Universidad de Deusto: Bilbao, Spain, 2012.

46. Hernández, R.; Fernández, C.; Baptista, P. Metodología de la Investigación, 5th ed.; McGraw-Hill: Mexico City, México, 2010.

47. Bisquerra, R. Metodología de la Investigación Educativa; Editorial La Muralla: Madrid, Spain, 2009.

48. Patton, M. Qualitative Research and Evaluation Methods; Sage: Thousand Oaks, CA, USA, 2002.

49. Arruti, A.; Paños-Castro, J. How do future primary education student teachers assess their entrepreneurship competences? An analysis of their self-perceptions. J. Entrep. Educ. 2020, 23, 1-13.

50. Villa, A.; Poblete, M. Competency-Based Learning: A Proposal for the Evaluation of Generic Competencies, 2nd ed.; University of Deusto: Bilbao, Spain, 2008.

51. Arruti, A.; Paños-Castro, J. International entrepreneurship education for pre-service teachers: A longitudinal study. Educ. Train. 2020, 62, 825-841. [CrossRef]

52. Gómez Llanos, L.M.; Hernández, T.; Mejía, D.; Heilbron, J.; Martín, J.; Mendoza, J.; Senior, D. Competencias emprendedoras en básica primaria: Hacia una educación para el emprendimiento. Pensam. Gestión 2017, 43, 150-188.

53. Paños-Castro, J. Educación emprendedora y metodologías activas para su fomento. Rev. Electrónica Interuniv. Form. Profr. 2017, 20, 33-48. [CrossRef] 